\title{
THE BIOAVAILABILITY OF PHOSPHOROUS FROM BONE MEAL AND TRIPLE SUPER PHOSPHATE AND ITS EFFECTS ON INDIGENOUS GROWING CATTLE
}

\author{
M. M. Rahman ${ }^{1}$, Z. H. Khandaker ${ }^{1}$ and A. B. M. Khaleduzzaman ${ }^{2}$
}

\begin{abstract}
The bioavailability of phosphorous, and blood serum and rumen liquor $\mathrm{P}$ level was studied in indigenous growing cattle by feeding bone meal and Triple Super Phosphate (TSP) with control diet. Nine indigenous growing cattle (live weight of $164 \pm 21 \mathrm{~kg}$ ) were randomly assigned in a Completely Randomized Design (CRD) to three dietary treatments, consisted of a basal diet $\left(\mathrm{T}_{0}\right)$ of $0.16 \% \mathrm{P}$ and experimental diets supplemented with bone meal $\left(T_{1}\right)$ and triple super phosphate $\left(T_{2}\right)$ to provide P level of $0.44 \%$. All diets were formulated to be iso-nitrogenous and iso-caloric. Three cannulated animals were used for rumen liquor $\mathrm{P}$ level study by feeding three diets. Apparent absorption and balance of $\mathrm{P}$ were significantly $(\mathrm{P}<0.01)$ higher in $\mathrm{T}_{1}$ and $\mathrm{T}_{2}$ diets than that of diet To, but true absorption did not differ significantly $(\mathrm{P}>0.05)$. Bioavailability of $\mathrm{P}$ of control diet $(37.41 \%)$, bone meal $(81.45 \%)$ and triple super phosphate $(80.49 \%)$ were significantly differed $(\mathrm{P}<0.01)$. Rumen liquor and blood serum $\mathrm{P}$ level differed significantly $(\mathrm{P}<0.01)$. Supplementation of bone meal and triple super phosphate results in high blood serum $\mathrm{P}$ $(\mathrm{P}>0.05)$ with no difference between bone meal and triple super phosphate. The results suggested that the bioavailability of $\mathrm{P}$ from bone meal and TSP was high and dietary supplementation of $\mathrm{P}$ with bone meal and TSP improved $\mathrm{P}$ retention and blood serum $\mathrm{P}$ level
\end{abstract}

Key words : Phosphorous, Bone meal, Triple super phosphate, Bioavailability, Growing cattle

\section{Introduction}

Phosphorous is necessary mineral for all mammalian biological system. Availability of $\mathrm{P}$ for microorganism in the rumen is important to ensure the maximum efficiency of digestion. A number of supplemental sources of $\mathrm{P}$ are available including calcium phosphates, ammonium phosphates, sodium phosphates, phosphoric acid, bone meal and sometimes fertilizer phosphates (triple super phosphate). There are considerable differences in the availability of mineral elements being provided from different sources. The bioavailability of minerals depends on the age and species of the animal; the intake of mineral and its needs; the chemical and physical form of ingested minerals and the amounts and the proportions of

\footnotetext{
${ }^{1}$ Department of Animal Nutrition, Bangladesh Agricultural University, Mymensingh-2202, Bangladesh

${ }^{2}$ Animal Nutrition Section, Department of Livestock Services, Krishi Khamar Sarak, Farmgate, Dhaka-1215
}

(Received : February 14, 2009) 
Bang. J. Anim. Sci. 2008, 37(2)

other dietary components with which it interacts metabolically. A number of response criteria have been used to evaluate $\mathrm{P}$ of livestock including growth rate, feed intake, feed efficiency mechanical criteria for several bones. Phosphorous concentration in bone (William et al., 1990), blood plasma (McDowell, 1985), rumen fluid (Cohen, 1973), faeces (Cohen, 1980), urine and forage have been suggested as indicators of P status. Some of these parameters could therefore be used to evaluate the availability of P. Since there are differences in the bioavailability of $\mathrm{P}$ for animal from different sources, therefore, nutritionally it may be sound if the bioavailability of $\mathrm{P}$ from different sources in cattle is known. Bone meal and Triple Super Phosphate (TSP) has been frequently used in animal diets in Bangladesh and therefore, the objectives of the present study was to investigate the bioavailability of P from bone meal and triple super phosphate and its effect on P level in blood and rumen liquor of indigenous growing cattle.

\section{Materials and Methods}

Nine indigenous growing cattle of 2.5 years having initial live weight of $164 \pm 21 \mathrm{~kg}$ were used in this experiment for a period of 60 days. The animals were randomly divided into three groups of three animals each in a completely randomized design (CRD). Three experimental diets were control $\left(\mathrm{T}_{0}\right)$ consisted of $69.08 \%$ rice straw, $12.65 \%$ dhal grass, $13.25 \%$ broken wheat, $4.02 \%$ soybean meal, $0.60 \%$ urea and $0.40 \%$ common salt and contained $0.16 \% \mathrm{P}$. To elevate the $\mathrm{P}$ level to $0.44 \%$, bone meal and triple super phosphate was used in diet $T_{1}$ and $T_{2}$ respectively. The composition of the dietary treatments is shown in Table 1. Three ruminally cannulated indigenous cattle were also used to study the $P$ contents in the rumen liquor for a period of 15 days of which the rumen liquor collection period was 5 days. Daily feed intake was recorded. At the middle of the experiment a metabolism trial was conducted for a period of 10 days of which last seven days was collection period. Blood sample $(10 \mathrm{ml})$ of experimental animals were collected in the morning before offering feed and water by punching the jagular vein at 15 days interval. Approximately $250 \mathrm{ml}$ of rumen liquor sample of individual cannulated animal was collected for period of three days. The rumen liquor samples were strained through 4 layers of muslin cloth, centrifuged and stored in the freeze. Phosphorous contents of feed ingredients, faeces, urine, rumen liquor and blood sample were determined according to the method of Page et al. (1982).

\section{Calculation}

Bioavailability and absorption of $\mathrm{P}$ was calculated for each animal. Bioavailability of supplemented $\mathrm{P}$ was calculated according to following equation:

$$
\text { Bioavailability of } \mathrm{P}=\frac{(\mathrm{INT} p-\mathrm{CONp})-(\mathrm{FECp}-\mathrm{CONFECp})}{\mathrm{INTp}-\mathrm{CONp}} \times 100
$$

$\mathrm{AAP}=\frac{\mathrm{INTp}-\mathrm{FECp}}{\mathrm{INTp}} \times 100$ 
$\mathrm{TAP}=\frac{\mathrm{INTp}-(\mathrm{FECp}-\mathrm{ENDp})}{\mathrm{INTp}} \times 100$

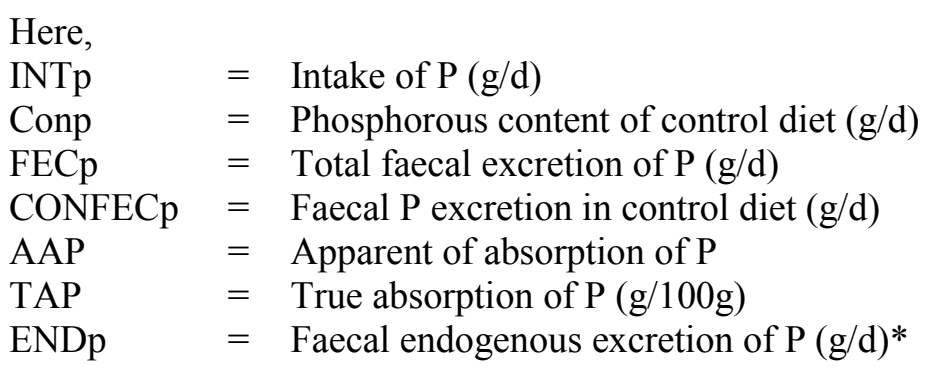

*ARC (1980) was used to predict faecal endogenous P excretion as $12 \mathrm{mg} / \mathrm{kg} \mathrm{LW} / \mathrm{d}$

The data were analyzed statistically using the analysis of variance in a Completely Randomized Design (CRD). The least significance difference (LSD) was used to compare treatment means (Steel and Torrie, 1980).

Table 1. Ingredients and nutrient composition of the experimental diets

\begin{tabular}{|l|c|c|c|}
\hline \multicolumn{1}{|c|}{ Parameters } & \multicolumn{2}{c|}{ Diets $^{\#}$} & $\mathbf{T}_{\mathbf{2}}$ \\
\cline { 2 - 4 } Ingredients (g/100 g DM) & $\mathbf{T}_{\mathbf{0}}$ & $\mathbf{T}_{\mathbf{1}}$ & \\
Rice straw & & & 68.31 \\
Dhal grass & 69.08 & 67.87 & 12.51 \\
Broken wheat & 12.65 & 12.43 & 13.11 \\
Soybean meal & 13.25 & 13.02 & 3.97 \\
Urea & 4.02 & 3.94 & 0.50 \\
Common salt & 0.60 & 0.49 & 0.40 \\
Bone meal & 0.40 & 0.39 & - \\
Triple Super Phosphate (TSP) & - & 1.87 & 1.10 \\
Nutrient composition (g/100 g DM) & - & - & 9.07 \\
CP & & & 29.37 \\
CF & 9.06 & 8.99 & 1.94 \\
EE & 29.03 & 29.11 & 46.92 \\
NFE & 1.97 & 1.95 & 12.7 \\
Ash & 47.10 & 46.62 & 0.44 \\
P (\%) & 12.84 & 13.33 & 7.2 \\
Estimated energy value* & 0.16 & 0.44 & \\
ME (MJ/ kg DM) & & & \\
\hline
\end{tabular}

${ }^{\#} \mathrm{~T}_{0}=$ Control $(0.16 \% \mathrm{P}), \mathrm{T}_{1}=$ Control + Bone meal $(0.44 \% \mathrm{P})$ and $\mathrm{T}_{2}=$ Control $+\mathrm{TSP}(0.44 \% \mathrm{P})$

*Energy value was estimated based on the energy concentration of feed ingredients (Khandaker and Uddin, 2002) 
Bang. J. Anim. Sci. 2008, 37(2)

\section{Results and Discussion}

Bioavailability of phosphorous, phosphorous absorption, phosphorous level in blood serum and rumen liquor from bone meal and TSP in the diet are shown in Table 2. The average daily $\mathrm{P}$ intake was $6.43,17.97$ and $17.49 \mathrm{~g}$ for growing bulls fed on diets containing $0.16 \%$ $\left(\mathrm{T}_{0}\right), 0.44 \%\left(\mathrm{~T}_{1}\right)$ and $0.44 \%\left(\mathrm{~T}_{2}\right) \mathrm{P}$ respectively and differed significantly $(\mathrm{P}<0.01)$. The animals fed on diets $T_{1}$ and $T_{2}$ showed significantly $(P<0.01)$ higher faecal excretion than that of animals fed on diet $T_{0}$. The faecal $P$ excretion of animals fed on diets $T_{1}$ and $T_{2}$ was almost the same. The average daily endogenous $\mathrm{P}$ excretion values were close for all dietary groups and did not differ significantly $(\mathrm{P}>0.05)$. The urinary excretion of $\mathrm{P}$ was significantly higher for treatment groups $\mathrm{T}_{1}(2.44 \mathrm{~g} / \mathrm{d})$ and $\mathrm{T}_{2}(2.10 \mathrm{~g} / \mathrm{d})$ compared to the animals fed on diet $\mathrm{T}_{0}(1.53 \mathrm{~g} / \mathrm{d})$. In a similar type of study, Morse et al. (1992) evaluated the effects of $\mathrm{P}$ excretion where twelve Holstein cows were fed diets containing three different $\mathrm{P}$ concentrations $(0.30,0.41$ and $0.56 \% \mathrm{P})$ and found that cows fed high $\mathrm{P}$ diet excreted 100.4 $\mathrm{g}$ P/d significantly more than the cows fed the low diets. Other studies have also shown an increase in faecal P and urinary P excretion with increase of dietary $\mathrm{P}$ (Call et al., 1986; Wu et al., 2001, and Knowlton and Herbein, 2002).

Table 2. Apparent and true absorption, balance and rumen liquor content of $P$ in growing bulls fed different experimental diets

\begin{tabular}{|c|c|c|c|c|c|}
\hline \multirow{2}{*}{ Parameters } & \multicolumn{3}{|c|}{ Diets $^{\#}$} & \multirow{2}{*}{ SED } & \multirow{2}{*}{$\begin{array}{l}\text { Level } \\
\text { of Sig. }\end{array}$} \\
\hline & $\mathbf{T}_{\mathbf{0}}$ & $\mathbf{T}_{1}$ & $\mathbf{T}_{2}$ & & \\
\hline \multicolumn{6}{|l|}{ DM intake (g/d) } \\
\hline Straw & 2556.7 & 2580.0 & 2570.0 & - & - \\
\hline Grass & 630.0 & 630.0 & 630.0 & - & - \\
\hline Concentrate & 890.0 & 986.0 & 946.0 & - & - \\
\hline Total DM intake $(\mathrm{g} / \mathrm{d})$ & 4076.7 & 4196.0 & 4176.0 & 101.05 & NS \\
\hline Phosphorous intake (g/d) & $6.43^{\mathrm{b}}$ & $17.97^{\mathrm{a}}$ & $17.49^{\mathrm{a}}$ & 0.06 & $* *$ \\
\hline Faecal excretion $(\mathrm{g} / \mathrm{d})$ & $4.03^{\mathrm{b}}$ & $6.17^{\mathrm{a}}$ & $6.10^{\mathrm{a}}$ & 0.68 & $* *$ \\
\hline Urinary excretion (g/d) & $1.53^{\mathrm{b}}$ & $2.44^{\mathrm{a}}$ & $2.10^{\mathrm{a}}$ & 0.28 & $*$ \\
\hline Total P excretion $(\mathrm{g} / \mathrm{d})$ & $5.56^{\mathrm{b}}$ & $8.60^{\mathrm{a}}$ & $8.20^{\mathrm{a}}$ & 0.72 & $* *$ \\
\hline Endogenous $\mathrm{P}$ (g/d) & 2.13 & 2.13 & 2.12 & 0.28 & NS \\
\hline Apparent absorption (g/100 g) & $37.41^{\mathrm{b}}$ & $65.68^{\mathrm{a}}$ & $65.12^{\mathrm{a}}$ & 4.73 & $* *$ \\
\hline True absorption (g/100 g) & 70.57 & 77.63 & 77.24 & 4.57 & NS \\
\hline Phosphorous balance (g/d) & $0.87^{\mathrm{b}}$ & $9.36^{\mathrm{a}}$ & $9.29^{\mathrm{a}}$ & 0.72 & $* *$ \\
\hline Rumen liquor P level (mg/l) & $151.26^{\mathrm{c}}$ & $225.03^{\mathrm{a}}$ & $216.24^{\mathrm{b}}$ & 4.64 & $* *$ \\
\hline
\end{tabular}

${ }^{\#} \mathrm{~T}_{0}=$ Control $(0.16 \% \mathrm{P}), \mathrm{T}_{1}=$ Control + Bone meal $(0.44 \% \mathrm{P})$ and $\mathrm{T}_{2}=$ Control $+\mathrm{TSP}(0.44 \% \mathrm{P})$

$\mathrm{SED}=$ Standard error of difference, $\mathrm{NS}=$ Non significant, $* \mathrm{P}<0.05, * * \mathrm{P}<0.01$

${ }^{\text {abc }}$ Mean values having different superscripts in a row differ significantly 
The apparent absorption of $\mathrm{P}(\mathrm{g} / 100 \mathrm{~g})$ was significantly $(\mathrm{P}<0.01)$ higher for dietary groups $T_{1}$ and $T_{2}$ than $T_{0}$. The true absorption of $P$ for supplemented diets $\left(T_{1}\right.$ and $\left.T_{2}\right)$ were numerically higher than control diet (Table 2 ) but did not differ significantly $(\mathrm{P}>0.05)$. Lofgreen (1960) reported apparent and true absorption of $\mathrm{P}$ by wethers from bone meal was $45.6 \%$ and $46.0 \%$ respectively of the animals fed on $3.86 \mathrm{~g} \mathrm{P} / \mathrm{d}$. These values are lower than that observed in the present experiment. It may be due to species differences. Though apparent absorption of $\mathrm{P}$ in different treatment groups differed significantly the true absorption did not differ significantly $(\mathrm{P}>0.05)$. This was because endogenous $\mathrm{P}$ excretion was almost same in different treatment groups but this excretion was higher in control diet in compare to intake and lowers the apparent absorption. When endogenous faecal $\mathrm{P}$ was subtracted from faecal $\mathrm{P}$ it increases the proportion of absorption of control diet. P balance was significantly $(P<0.01)$ higher in diets $T_{1}(9.36 \mathrm{~g} / \mathrm{d})$ and $\mathrm{T}_{2}(9.29 \mathrm{~g} / \mathrm{d})$ compared to diet $\mathrm{T}_{0}$ $(0.87 \mathrm{~g} / \mathrm{d})$.

The bioavailability of P (Table 3) from bone meal (81.45\%) and TSP (80.49\%) were significantly $(\mathrm{P}<0.01)$ higher than that of control $(37.41 \%)$ diet. However, the value for bone meal and TSP did not differ significantly $(\mathrm{P}>0.05)$. From these results it is indicated that more $\mathrm{P}$ is available from bone meal and TSP in the animal body for metabolism. Chase (2002) reported that biological availability of $\mathrm{P}$ from monocalcium phosphate, dicalcium phosphate, defluorinated phosphate, steam bone meal were 95-98, 93-95, 88-91 and 80-82\% respectively. Similarly, bone meal, ammonium phosphate and super phosphate have been reported to have an equal $\mathrm{P}$ availability to dicalcium phosphate (Long et al., 1957 and Gutierrez et al., 1983).

Table 3. Bioavailability of $P$ from different sources

\begin{tabular}{|c|c|c|c|c|c|}
\hline \multirow{2}{*}{ Parameters } & \multicolumn{3}{|c|}{ Diets $^{\#}$} & \multirow{2}{*}{ SED } & $\begin{array}{c}\text { Level } \\
\text { of Sig. }\end{array}$ \\
\cline { 2 - 5 } & $\mathbf{T}_{\mathbf{0}}$ & $\mathbf{T}_{\mathbf{1}}$ & $\mathbf{T}_{\mathbf{2}}$ & & $* *$ \\
\hline Phosphorous intake (g/d) & $6.43 \mathrm{~b}$ & $11.54^{\mathrm{a}}$ & $11.08^{\mathrm{a}}$ & 0.50 & $* *$ \\
Phosphorous outgo (g/d) & $4.03^{\mathrm{b}}$ & $1.98^{\mathrm{a}}$ & $2.16^{\mathrm{a}}$ & 0.42 & $* *$ \\
Bioavailability of P (\%) & $37.41^{\mathrm{b}}$ & $81.45^{\mathrm{a}}$ & $80.49^{\mathrm{a}}$ & 3.98 & $* *$ \\
\hline
\end{tabular}

${ }^{\#} \mathrm{~T}_{0}=$ Control $(0.16 \% \mathrm{P}), \mathrm{T}_{1}=$ Control + Bone meal $(0.44 \% \mathrm{P})$ and $\mathrm{T}_{2}=$ Control $+\mathrm{TSP}(0.44 \% \mathrm{P})$

$\mathrm{SED}=$ Standard error of difference, ${ }^{* *} \mathrm{P}<0.01$

${ }^{\mathrm{abc}}$ Mean values having different superscripts in a row differ significantly

Ruminal P level is the indicator of the availability of $\mathrm{P}$ for rumen microorganisms which influence the crude fiber digestibility and microbial protein synthesis in the rumen. The $\mathrm{P}$ content of rumen liquor (Table 2$)$ were significantly $(\mathrm{P}<0.01)$ higher for the animals fed on diets $T_{1}$ and $T_{2}$ than that of the animals fed control diet. The results of the present experiments agreed with the findings of Cohen (1980) who reported higher (183 mg P/l) rumen liquor $P$ in heifer with intakes of dietary $P$ of $15.0 \mathrm{~g} / \mathrm{d}$ compare to $5.0 \mathrm{~g} / \mathrm{d}(150 \mathrm{mg}$ $\mathrm{P} / 1$ ). Witt and Owens (1983) also reported that steer receiving diets containing $0.12 \% \mathrm{P}$ and 
Bang. J. Anim. Sci. 2008, 37(2)

$0.23 \% \mathrm{P}$ had significance difference in the level of rumen liquor $\mathrm{P}$ and the value was 208.10 $\mathrm{mg} / \mathrm{l}$ and $398.10 \mathrm{mg} / \mathrm{l}$ respectively.

A number of response criteria have been used to evaluate $\mathrm{P}$ status of cattle of which serum $\mathrm{P}$ level is one of them. The first known response to a dietary deficiency of $\mathrm{P}$ is a fall in the inorganic $\mathrm{P}$ fraction of the blood serum. Serum $\mathrm{P}$ is a good indicator of $\mathrm{P}$ status of ruminant only if stress factors, time of sampling and blood preparation can be strictly controlled (McDowell, 1985). In this study mean serum $\mathrm{P}$ concentration is affected by the supplementation of $\mathrm{P}$ and increased significantly $(\mathrm{P}<0.01)$ with higher $\mathrm{P}$ diet. Mean serum $\mathrm{P}$ concentration near the critical level of $4.5 \mathrm{mg} / \mathrm{dl}$ (McDowell, 1985) were found (Table 4) for diet $\mathrm{T}_{0}$ throughout the experimental period and for diet $\mathrm{T}_{1}$ and $\mathrm{T}_{2}$ before administration of bone meal and TSP with control diet.

Table 4 Changes of serum inorganic $P(\mathrm{mg} / \mathrm{dl})$ in different dietary treatments

\begin{tabular}{|c|c|c|c|c|c|}
\hline \multirow{2}{*}{ Collection period } & \multicolumn{3}{|c|}{ Diets $^{\#}$} & \multirow{2}{*}{ SED } & \multirow{2}{*}{$\begin{array}{l}\text { Level } \\
\text { of Sig. }\end{array}$} \\
\hline & $\mathbf{T}_{\mathbf{0}}$ & $T_{1}$ & $\mathbf{T}_{2}$ & & \\
\hline 0 week & 4.22 & 4.22 & 4.21 & 0.20 & NS \\
\hline $2^{\text {nd }}$ weeks & $4.55^{\mathrm{b}}$ & $5.72^{\mathrm{a}}$ & $5.83^{\mathrm{a}}$ & 0.97 & $*$ \\
\hline $4^{\text {th }}$ weeks & $4.43^{\mathrm{b}}$ & $5.69^{\mathrm{a}}$ & $5.87^{\mathrm{a}}$ & 0.34 & $* *$ \\
\hline $6^{\text {th }}$ weeks & $4.41^{\mathrm{b}}$ & $6.02^{\mathrm{a}}$ & $5.98^{\mathrm{a}}$ & 0.51 & $*$ \\
\hline $8^{\text {th }}$ weeks & $4.38^{\mathrm{b}}$ & $5.91^{\mathrm{a}}$ & $6.15^{\mathrm{a}}$ & 0.58 & $*$ \\
\hline Mean $^{@}$ & $4.44^{\mathrm{b}}$ & $5.84^{\mathrm{a}}$ & $5.96^{\mathrm{a}}$ & 0.51 & $* *$ \\
\hline
\end{tabular}

${ }^{\#} \mathrm{~T}_{0}=$ Control $(0.16 \% \mathrm{P}), \mathrm{T}_{1}=$ Control + Bone meal $(0.44 \% \mathrm{P})$ and $\mathrm{T}_{2}=$ Control $+\mathrm{TSP}(0.44 \% \mathrm{P})$

$\mathrm{SED}=$ Standard error of difference, $\mathrm{NS}=$ Non significant, $* \mathrm{P}<0.05, * * \mathrm{P}<0.01$

abc Mean values having different superscripts in a row differ significantly

Mean ${ }^{\circledR}=2^{\text {nd }}$ to $8^{\text {th }}$ collection

After introduction of supplemental $\mathrm{P}$ from bone meal $\left(\mathrm{T}_{1}\right)$ and TSP $\left(\mathrm{T}_{2}\right)$, the serum P increased significantly and maintained almost this level throughout the experimental period. Triple super phosphate $\left(T_{2}\right)$ produced higher $P$ level of blood serum than bone meal when both were added (11.54 and $10.08 \mathrm{~g} \mathrm{P} / \mathrm{d}$ ) to the control diet but the difference was not significant $(\mathrm{P}<0.05)$. The higher serum $\mathrm{P}$ level due to addition of bone meal and TSP is because it is directly affected by $\mathrm{P}$ intake in young calves (Challa and Braithwaite, 1988) and by dry matter intake (g/kg LW) in weaning steers (Bortolussi et al., 1996). Williams et al. (1991) reported that blood serum P concentrations after 79 days of treatment were 5.79 and $6.18 \mathrm{mg} / \mathrm{dl}$ on treatment diets of 0.12 and $0.20 \% \mathrm{P}$ respectively. Ingalls and Okema (1994) reported that plasma or serum $\mathrm{P}$ concentrations were affected by the $\mathrm{P}$ supplementation. They fed the growing calves on diets 0.25 and $0.32 \% \mathrm{P}$ and mean serum $\mathrm{P}$ concentrations were 8.73 and $9.61 \mathrm{mg} / \mathrm{dl}$ respectively. The results suggested that the bioavailability of $\mathrm{P}$ 
from bone meal and TSP was high and dietary supplementation of P with bone meal and TSP improved P retention and blood serum P level.

\section{Acknowledgement}

The authors acknowledge the financial assistance from Bangladesh Agricultural University Research System (BAURES), Bangladesh Agricultural University, Mymensingh.

\section{Literature Cited}

ARC, 1980. The Nutrient Requirements of Ruminant Livestock. Commonwealth Agricultural Bureaux, Slough, U.K.

Bortolussi, G., Ternouth, J. H. and McMeniman, N. P. 1996. Dietary nitrogen and phosphorous depletion in cattle and their effects on live weight gain, blood metabolic concentrations and phosphoric kinetics. J. Agric. Sci. (Camb.) $126: 493-501$.

Call, J. W., Butcher, J. E., Shupe, J. L., Blake, J. T. and Olson, A. E. 1986. Dietary phosphorous for beef cows. Am. J. Vet. Res. 47 : 475-481.

Challa, J. and Braithwaite, G. D. 1988. Phosphorous and calcium metabolism in growing calves with special emphasis on phosphorous homeostasis. 3. Studies of the effect of changes in the dietary phosphorous intake on phosphorous and calcium metabolism. J. Agric. Sci. (Camb.) $110: 573-581$

Chase, L. E. 2002. Phosphorous in dairy cattle nutrition. Department of Animal Science. Cornell University.

Cohen, R. D. H. 1973. Phosphorous nutrient in beef cattle. The use of faecal and blood phosphorous for the estimation of phosphorous intake. Aust. J. Exp. Agric. Anim. Husbandry. 14 : 709-704.

Cohen, R. D. H. 1980. Phosphorous in rangeland ruminant nutrition. A review. Liv. Prod. Sci. 7 : 25-37

Gutierrez, O., Geetken, C. M. and Diaz, A. 1983. A note on the phosphorous balance of calves fed natural super phosphate supplemented diets. Cuban J. Agric. Sci. $17: 51$

Ingalls, J. R. and Okemo, R. C. 1994. The bioavailability of phosphorous from canola meal as measured by Holstein calves and mobile bag techniques. Animal Feed Sci. and Tech. 47 : 321-334

Khandaker, Z. H. and Uddin, M. M. 2002. Nutritional evaluation of locally available feedstuffs in Bangladesh. Indian J. Anim. Nutr. 19(2) : 110-115.

Knowlton, K. F. and Herbein, J. H. 2002. Phosphorous partitioning during early lacation in dairy cows fed diets varying in phosphorous contents. J. Dairy Sci. 85 : 1227-1236

Lofgreen, G. P. 1960. The availability of phosphorous in dicalcium phosphate and bone meal soft phosphate, and calcium phytate for mature wethers. J. Nutr.70:58

Long, T. A., Tillman, A. D., Nelson, A. B., Gallup, W. D. and Davis, B. 1957. Availability of phosphorous in mineral supplements for beef cattle. J. Anim. Sci. $16: 444$ 
Bang. J. Anim. Sci. 2008, 37(2)

McDowell, L. R. 1985. Calcium, phosphorous and fluorine. In: Nutrition of grazing ruminants in warm climates (Editors: Mcdowell), Academic press, Orlando, Florida. pp. 216-241

Morse, D., Head, H. H., Wilcox, C. J., Van-Horn, H. H., Hisem, C. D. and Harris, Jr. B. 1992a. Effect of concentration of dietary phosphorous on amount and rout of excretion. J. Dairy Sci. 75 : 3039-3049

Page, A. L., Miller, R. H. and Keeney, D. R. 1982. Method of soil analysis Part-2. Amer. Soc. Agron. Inc. Soil Sci. Soc. America. Inc. Madison. Wisconsin. USA. pp. 152-531

Steel, R. G. D. and Torrie, J. H. 1980. Principles and Procedures of Statistics. McGraw-Hill Book Co., New York.

Williams, S. N., Lawrence, L. A., Mcdowell, L. R., Warnick, A. C. and Wilkinson, N. S. 1990. Dietary phosphorous concentrations relating to breaking load and chemical bone properties in heifers. J. Dairy Sci.73 : 1100-1106

Williams, S. N., Mcdowell, L. R., Warnick, A. C., Wilkinson, N. S. and Lawrence, L. A. 1990. Phosphorous concentrations in blood, milk, faeces, bone and selected fluids and tissues of growing heifers as affected by dietary phosphorous. Fla. Beef Cattle Res. Rep. Fla. Coop. Ext. Ser. Univ. Fla. pp. 118-121

Witt, K. E. and Owens F. N. 1983. Phosphorous: Ruminal availability and effects on digestion. J. Anim. Sci. 56 : 930-937

Wu, Z., Satter, L. D., Blohowiak, A. J., Stauffacher, R. H. and Wilson, J. H. 2001. Milk production, estimated phosphorous excretion and bone characteristics of dairy cows fed different amounts of phosphorous for two or three years. J. Dairy Sci. 84 : 1738-1748. 